\title{
Morphometric Studies on the Skull in Three Mar- supial Species (Koala, Wombat, Wallaby)
}

\author{
A. S. Saber ${ }^{1,2}$ and B. Gummow ${ }^{2,3}$ \\ ${ }^{1}$ Faculty of Veterinary Medicine, University of Sadat City, Sadat City, Egypt \\ ${ }^{2}$ Dicipline of Veterinary Sciences, College of Public Health, Medical and Veterinary \\ Sciences, James Cook University, Townsville, Australia \\ ${ }^{3}$ Faculty of Veterinary Science, University of Pretoria, Pretoria, South Africa
}

With 4 figures, 2 tables

Received June, accepted for publication July 2014

\section{Abstract}

Although many gross anatomical studies are published on Phascolarctos cinereus (Koala), Vombatus ursinus (Wombat) and Macropus greyi (wallaby) there appear to be no morphometric studies on the skull of these species. Traditional morphometric data are useful when either absolute or relative sizes are of particular interest, such as in studies of growth. These data are also useful when size measurements are of theoretical importance in studies of functional morphology.

Three koala, two wombat and three Grey's wallaby skulls were used in this traditional morphometric study. All estimated morphometric data were expressed as means $\pm S D$ with the maximum and minimum values. The skull weight (with mandible) was $44.4 \pm 8.1 \mathrm{~g}, 224.5 \pm 50.2 \mathrm{~g}$, $55.7 \pm 23.1 \mathrm{~g} \&$ the skull length was $12.0 \pm 0.9 \mathrm{~cm}, 16.6 \pm 0.8 \mathrm{~cm}, 13.2$ $\pm 1.4 \mathrm{~cm}$ \& the cranial length was $8.7 \pm 1.1 \mathrm{~cm}, 10.4 \pm 0.5 \mathrm{~cm}, 7.7 \pm 0.4$ $\mathrm{cm}$. The skull index was 58.333 , $77.71,56.06$, cranial index 60.92, 50.96 , 54.55, facial index 186.11, $148.44,114.29$ and orbital index $90.00,85.294,91.304$, and cranial capacity $20.0 \pm 2.4 \mathrm{cc}, 61.7 \pm 11.8 \mathrm{cc}$, $33.5 \pm 3.7 \mathrm{cc}$ in the koala, wombat and wallaby respectively. These results were discussed in terms of the usage of these morphometric measurements in several basic and clinical applications as well as in evaluating the intelligence status of these species. Two tables and four figures supported the results of this study.

Keywords: Marsupials, Koala, Wombat, Wallaby, Cranial capacity, Morphometry, Skull.

\section{Introduction}

Marsupials are an infraclass of mammals living primarily in Australasia and the New World. A distinc- 
tive characteristic, common to most species, is that the young are carried in a pouch. Well-known marsupials include kangaroos, wallabies, koala, possums, opossums, wombats and the Tasmanian devil ${ }^{1}$.

These marsupial species are usually kept in Australian Native Animal Wildlife Parks and special sanctuaries such as Billabong Sanctuary in Townsville, Wombat Rise sanctuary in Sedon, South Australia, Sleepy Burrows wombat Sanctuary, Epping Forest National Park in QLD, Koala Park in New South Wales, and Lone Pine Koala Sanctuary in Brisbane, as well as in the zoo gardens in Australia and around the world.

The koala (Phascolarctos cinereus) is a famous marsupial, which has eco-morphological and behavioral peculiarities such as sedentary, solitary, arboreal and tailless, small brain and enormous guts (proportionally, the largest of any mammal), is specialized for a diet of eucalyptus. It is virtually able to go without drinking (the aborigines meaning of Koala is: I don't drink, Beatty, 1972), Koala, unlike most macropodes and diproto-dontoids, which are lophodont, has selenodont molars. Koalas famously possess human-like fingerprints (Naish, 2011).

The wombat (Vombatus ursinus) is a short-legged, muscular quadrupedal marsupial, native to Australia.
Wombat digs extensive burrow systems with rodent-like front teeth and powerful claws. One distinctive adaptation of the wombat is its backwards pouch. The advantage of a backwards-facing pouch is that when digging, the wombat does not gather soil in its pouch over its young. Wombats are herbivores; their diets consist mostly of grasses, sedges, herbs, bark, and roots. All three known extant species average around a meter in length and weigh between 20 and $35 \mathrm{~kg}$ (Wikipedia, retrieved 15/3/2014).

A wallaby (Macropus greyi) is an informal designation generally used for any macropod that is smaller than a kangaroo or wallaroo that has not been designated otherwise. Wallabies are herbivores whose diet consists of a wide range of grasses, vegetables, leaves, and other foliage. Their powerful hind legs are not only used for bounding at high speeds and jumping great heights, but also to administer vigorous kicks to fend off potential predators. Wallabies also have a powerful tail that is used mostly for balance and support (Wikipedia, retrieved15/3/2014)

Although many gross anatomical studies were published on each of the three marsupial species (Forbes, 1881; Young, 1882; Beddard, 1902; Mackenzie 1918a,b; Sonntag, 1921, 1922; Flower, 1966; 
Hyett and Shaw, 1980; Kempster and Hirst, 2002; Louys et al., 2009) no morphometric studies of the skull of any of the three species could be found in the available literature. Hence, the goal of this study is to give some morphometric information and indices of the skull as well as the cranial capacity in these three marsupial species; koala, wombat and wallaby.

\section{Material and Methods}

Three Koala (Phascolarctos cinereus), Three Grey's wallaby (Macropus greyi), and two wombat (Vombatus ursinus) frozen heads, kept in the Discipline of Anatomy and $\mathrm{Pa}$ thology, Dicipline of Veterinary Sciences, College of Public Health, Medical and Veterinary Sciences, James Cook University, Townsville, Australia, were used in this study. Neither the sex nor age was recorded with the heads. The skulls were prepared using the boiling maceration technique for skeleton preparation described by Simoens et al., (1994). The following external measurements were taken as described by Sarma (2006): the skull length, skull width, cranial length, cranial width, facial length, facial width, skull weight, orbital height, orbital width, inter orbital distance (rostral, middle and caudal), mandibular length and mandibular weight.
For measuring the orbital capacity, foramina opening into the orbital cavity, were plugged with plasticin (plastic clay) and /cotton. The communication between the orbital cavity and temporal fossa was blocked with cotton and the whole orbital cavity was lined with a very thin tissue. Then the cavity was filled with mustard seeds to the level of the orbital rim. The contents were emptied and measured in a measuring cylinder. For measuring the cranial capacity, all the foramina of the cranial cavity were plugged with cotton. The cavity was then filled with mustard seeds through the foramen magnum up to its brim. The mustard seeds were then emptied into a measuring cylinder to measure the capacity.

The cranial, facial and orbital indices were determined using the following equations mentioned by Miller et al., (1964):
a) Cranial index $=\frac{\text { Cranial width }}{\text { Cranial length }} \times 100$
b) Facial index $=\frac{\text { Facial width }}{\text { Facial length }} \times 100$
c) Orbital index $=\frac{\text { Orbital width }}{\text { Orbital length }} \times 100$
d) Skull/cephalic index $=\frac{\text { Skull width }}{\text { Skull length }} \times 100$

\section{Skull Parameters:}

a) Cranial length: Distance between the highest point of the parietals to 
the middle of the rostral margin of the incisive bone.

b) Cranial width: Distance between two zygomatic arches.

c) Weight of the skull: Weight of the skull (excluding the mandible).

\section{Cranial Parameters:}

a) Cranial length: Distance from the central point of the fronto-nasal suture to the middle point of the nuchal crest.

b) Cranial width: Maximum distance between the highest points of the parietal bones.

\section{Orbital parameters:}

a) Orbital length: The perpendicular distance between the supraorbital and infraorbital margins of the orbit.

b) Orbital width: The horizontal distance between the rostral and caudal margins of the orbital rim.

c) Inter-orbital distance:

i. At rostral level: Distance between the junction of frontolacrimal sutures of either side at the rostral margin of the orbit.

ii. At middle level: Distance between the supraorbital borders of orbit on either sides. iii. At caudal level: Distance between the junctions of the zygomatic bone at the caudal margin of the orbit on either sides.

\section{Facial Parameters:}

a) Facial length: Distance from the frontonasal suture to the center of the incisive bone.

b) Facial width: Distance between the caudal extents of the orbital rims.

c) Mandibular length Distance between incisor and caudal border of the mandible.

\section{Data Analysis}

Data was stored and analyzed using Microsoft Excel 2010. The carniometric measurements were taken using a normal caliper. Photographs were taken by a Samsung digital camera WB700. Nomina Anatomica Veterinaria (2005) was utilized for denominating the anatomical terms in the study.

\section{Results}

In the present study, the skull length of the koala, wombat and wallaby was $12.3 \pm 0.9,11.6 \pm 0.8,9.9 \pm 1.4 \mathrm{~cm}$ respectively, the cranial length was $8.7 \pm 1.1,10.4 \pm 0.5,7.7 \pm 0.4 \mathrm{~cm}$ respectively, while the facial length was $3.6 \pm 0.6,5.4 \pm 0.6,5.6 \pm 1.3 \mathrm{~cm}$ respectively. The skull width was 
$7 \pm 0.6,12.9 \pm 0.5,7.4 \pm 0.7$ in the koala, wombat and wallaby respectively. The cranial width was $5.3 \pm 1.4,5.3 \pm 0.5,4.2 \pm 0.2 \mathrm{~cm}$ and the facial width was $6.7 \pm 0.5$, $9.5 \pm 3.0,6.4 \pm 0.5$ respectively ( $\mathrm{Ta}-$ ble 1).

In addition, the cranial index in the koala was 60.919, in the wombat was 50.961 and in the wallaby was 54.545 , where as the facial index was $186.111,148.437$ and 114.286 in the three species respectively (table 2). The orbital indices were $90.00,85.294$ and 91.304 respectively. The skull (cephalic) index was $58.333,77.710$ and 56.060 in the three species respectively ( $\mathrm{Ta}$ ble 2).

The cranial capacity estimated was $20.0 \pm 2.4 \mathrm{cc}, 61.7 \pm 11.8 \mathrm{cc}, 33.5 \pm$ $3.7 \mathrm{cc}$ for the koala, wombat and wallaby respectively (Table 1 ).

\section{Discussion}

Although many gross anatomical studies are published on Phascolarctos cinereus (Koala), Vombatus ursinus (Wombat) and Macropus greyi (wallaby) there appear to be no morphometric studies on the skull of these species. Traditional morphometric data are useful when either absolute or relative sizes are of particular interest, such as in studies of growth. These data are also useful when size measurements are of theoretical importance in studies of functional morphology. Three koala, two wombat and three Grey's wallaby skulls were used in this traditional morphometric study. The small sample size is a weakness of the study as well as knowing the exact age or sex of the animals sampled. How representative of the general population these skulls are is therefore uncertain. However, since no morphometric studies appear to have been previously done this study serves as starting point.

Using the muster seeds for measuring the cranial and orbital capacities was preferred by many authors because of the rounded shape and small size of the seeds (Saber, 1989; Sarma, 2006). However, some authors used sesame seeds (Rao, 1967) and rice grains (Olopade and Onwuka, 2008). More recently, other authors have used more modern techniques such as computed tomographic images and scanograms as well as $\mathrm{X}$-ray images of live animals for measuring, calculating and analysing the different parameters and indices (Onar et al., 2002 and Alpak, 2003 \& Kock et al., 2012).

Several authors have previously studied the skull morphometry of 
domestic animals (Monfred et al., 2013a-k; Karimi et al., 2011; Sarma, 2006; Olopade et al., 2005; Sarma and Samara, 2002; Onar et al., 2001; Onar, 1999; Regedon et al. 1991, 1992; Saber 1989; Sandhu and Dhingra, 1986; Brehm et al., 1985; Roa, 1967 and Miller et al., 1964), and wild animals such as the African giant rat (Olude and Olopade, 2010), and the yak (Sudhakar and Sharma, 1998). Yet, no published work on the morphometry of any of the marsupial species could be found in the available literature.

Hajnis (1962) stated that the skull capacity is in no way dependent on the form of the skull. This opinion is accepted also in the sheep and goat as confirmed by Saber (1989)

Monfared (2013 g, h, i, j,) estimated 66.37 for the adult Iranian mixedbreed dog's cranial index, 71.28 for the Golden Jackal, 55.55 for the Persian cat's skull and 50.81 for the rabbits respectively. Karimi et al., (2011) estimated $52.76 \pm 1.13$ as the cranial index and $130.86 \pm$ 11.55 for the cranial volume in Mehraban Sheep. The cranial index of the koala, wombat and wallaby of this study was 48.78, 111.21 and 74.75 respectively.

The skull index of the koala, wombat and wallaby of this study was 48.78, 111.21 and 74.75, whereas the facial index was $186.11,175.24$ and 114.29 respectively (Table 4).

Different values of cranial capacity for a number of animal species and man are given in Table (3).

The koala's brain size is about $60 \%$ of what would be expected. It is about $0.2 \%$ of the body weight. In humans, the brain is about $2 \%$ of body mass ${ }^{1}$. In addition, the koala's brain is much smaller than the inside of the skull (in most mammals, the difference between the size of the inner cranium and the size of the brain is $20 \%$. In koalas, about $40 \%$ of the cranium is filled with cerebrospinal fluid ${ }^{1}$. Flannery (1995) mentioned that the hemispheres of the koala's brain sit like a pair of shriveled walnut halves on the top of the brain stem, in contact neither with each other nor the bones of the skull. He added that koala is the only mammal on earth with such a strangely reduced brain with its smooth surface and reduced parts associated with motor movements.

The relationship between the brain capacity/size and intelligence was studied in school children by Estabrooks (1928), as well as studied in animals by Hicks and Dougherty (2013). Considering the before mentioned studies about the brain size of koala and the results of the present study estimating the koala cra- 
nial capacity as $20 \pm 2.4 \mathrm{cc}$, we can did not express the real size of the koala's brain and in turn its intelligence.

Accordingly, we can agree with Pratt (1937) who mentioned that the koala's intelligence, is probably limited to its ability to learn from experience (like not go near things that hurt it) and the ability to distinguish between eucalyptuses. Moreover, Koala have a niche that is fairly secure, spending almost all their time relatively safe in trees, which provide them with all their food. In order to make this niche work they need to be cautious in their utilization of energy. They don't really need all that much brain to survive- or that much variety in living. This lifestyle works for them-and has for the past twenty-five million years or so ${ }^{1}$.

The cranial capacity/size in wombats and wallabies, although not fully studied, reflect, to some extent, sufficient intelligence for getting food and water, managing its territory, offense and defense actions, and avoiding dangerous situations. This agrees with Hieck and Dougherty (2013) who said that animals that were predators in comparison to prey were of a higher intelligence.

The orbital capacity estimated for the koala, wombat and wallaby of this study were $2.9 \pm 0.6,8.6 \pm 1.2$ and $4.6 \pm 1.2$ cc respectively, while the orbital indices were 90.00, 85.294 and 91.304 respectively. It worthy to mention that the koala orbit is directed more rostrally (Kempster and Hirst, 2002) than laterally like the case in wombat and wallaby.

The present study has provided baseline data on the skull osteometry of the koala, wombat and wallaby that will be of importance in paleontological studies (Yahaya et al., 2012) as well as will be useful for comparative anatomical and developmental studies, and for clinicians who work on these animal species in the sanctuaries and zoo.

\section{References}

Beddard, F. (1958): Mammalia, Vol. X. a reprint edition from 1902, by Macmillan \& Co., Limited

Brehm, H.K. Loeffler, K. and Komeyli, H. (1985): Skull shape in the dog. Anat. Histol. Embryol. 14: 324-331.

Camoron, J. (1928): Craniometric studies. XII Correlation between cranial capacity and cranial length, breadth as studies in the Alska Indian crania. Amer.J.Phys. Athrop. II: 290-299 
Chaturvedi, R.P. and Harneja, N.K. (1962): Cranial capacity, facial angles and gnathic index in adult human skulls. J. Anat. Soc. India., II: $18-23$

Drennan, M.R. (1927): A contribution to the Piltdown problem. Nayure, 120 (3033): 874

Estabrooks, G.H. (1928): The relationship between cranial capacity, relative cranial capacity and intelligence in school children. Journal of Applied Psychology, Vol 12(5): 524529.

Flannery, T. (1995): The future eaters: an ecological history of the Australian lands and people. New York: G.Braziller.

Flower, W.H. (1966): An introduction to the osteology of the mammalia, Asher, Amsterdam

Forbes, W.A. (1881): On some points in the anatomy of the koala (Phascolarctos cinereus) Proc Zool Soc Lond 18: 180-195

Hajnis, K. (1962): Evaluation of different methods of calculation of skull capacity for lineal Measurements. Ceskolov.Merfol., 10:220233- cited by G.S.Rao (1967)
Hieck, K. and Dougherty, $M$. (2013): Finding the intelligence of an animal. Field study presented to STEM Teacher Academy, Rider University.

http://riderstem.weebly.com/crani al-volume-intelligence.html

Hyett, J. and Shaw, J. (1980): Australian Mammals, A field guide for New South Wales, Victoria, South Australia \& Tasmania. Thomas Nelson Australia.

Jue, D.S. (1990): Cranial capacity and endocranial casts. TJ 4(1):5665

Kempster, R.C. and Hirst, L.W. (2002): Bony Orbital Anatomy of the Koala (Phascolarctos cinereus).The Anaomical record, 267: 288-291

Lynn, R. (2006): Race Differences in Intelligence: An Evolutionary Analysis. ISBN 1-59368-021-X

Louys, J., Aplin K., Beck, R M.D. and Archer, M. (2009): Cranial Anatomy of Oligo-Miocene Koalas (Diprotodontia: Phasscolaretidae): Stages in the Evolution of an Extreme Leaf-Eating Specialization. Journal of Vertebrate Paleontology, 29 (4): 981-992. 
Mackenzie, W.C. (1918a): The gastro-intestinal tract in monotremes ans marsupials. Critchley Parker, Austrlia $104 \mathrm{pp}$

Mackenzie, W.C. (1918b): The liver, spleen, pancreas, peritoneal relation and biliary system in monotremes and marsupials. Critchley Parker, Austrlia 157 pp

Malik, M.R. and Shankar, K. (1979): Relationship among skull parameters and prediction of endocranial volume in pig. Indian Veterinary Medical Journal 3: 237-241

Monfared, A.L. (2013a): Some Aspects of Clinical Anatomy of the Head Region of the Caspian Miniature Horse and its Clinical Value During Regional Anesthesia. Global Veterinaria 10 (2): 214-218.

Monfared, A.L. (2013b): Gross Anatomical Measurements of the Head Region of the Iranian Native Cattle (Bos taurus) and Their Clinical Value for Regional Anesthesia. Global Veterinaria 10 (2): 219-222.

Monfared, A.L. (2013c): Clinical Anatomy of the Skull of Iranian Native Sheep. Global Veterinaria 10 (3): 271-275.

Monfared, A.L. (2013d): Applied anatomy of the head regions of the One-humped camel (Camelus
Monfared, A.L. (2013j): Applied
Anatomy of the Rabbit's Skull and
its Clinical Application During Re-

Monfared, A.L. (2013j): Applied
Anatomy of the Rabbit's Skull and
its Clinical Application During Re-

Monfared, A.L. (2013j): Applied
Anatomy of the Rabbit's Skull and
its Clinical Application During Re-

dromedaries) and its clinical implications during regional anesthesia. Global Veterinaria 10 (3): 322-327.

Monfared, A.L. (2013e): Gross Anatomy of the Head Region of the Iranian Native Horse and its Clinical Value During Regional Anesthesia. Global Veterinaria 10 (4): 403-407..

Monfared, A.L. (2013f): Craniometrical and gross Anatomical Studies on the Iranian Buffaloes and Their Clinical Value for Regional Anesthesia. Global Veterinaria 10 (4): 427-431.

Monfared, A.L. (2013g): Anatomical study of the skull of the adult dogs and its Clinical Value During Regional Anesthesia. Global Veterinaria 10 (4): 459-463.

Monfared, A.L. (2013h): Macroanatomical Investigation of the Skull of Golden Jackal (Canis aureus) and its clinical Application during Regional Anethesia. Global Veterinaria 10 (5): 547-550.

Monfared, A.L. (2013i): Anatomy of the Persian Cat's skull and its clinical value during regional anesthesia. Global Veterinaria 10 (5): 551555. 
gional Anesthesia. Global Veterinaria 10 (6): 653-657

Monfared, A.L. (2013k): anatomy of the head region of the Iranian native donkeys and its clinical value during regional anesthesia. Global Veterinaria 10 (6):658-662.

McHenry, Henry M. (2002). "23: Introduction to the fossil record of human ancestry", in Walter C. Hartwig: The Primate Fossil Record (in English). Cambridge University Press, 402. 0521663156

Miller,M.S.; Christensen,G.C, and Evans,H.E. (1964): The skeletal system, skull. In anatomy of Dog. Pp. 6-49. W.B.Saunders Co., Philadelphia.

Olopade, J.O. and Onwuka S.K. (2005): Morphometric study of the skull of the West African Dwarf goat from South West Nigeria. Nigerian Veterinary Journal Vol. 26 (2):18-21.

Olude, M.A. and Olopade J.O. (2010): Morphometric Studies of the Axial Skeleton of the African Giant Rat (Cricetomys gambianus, Waterhouse) Part (I): Skull Typology. J Vet Anat, Vol 3, No 2: 1-12

Pratt. A. (1937): The call of the koala, Melbourne: Robertson\& Mullens.
Regedon, S.; Franco, A. ; Lignereux, Y.; Garin, J. and Martin, A. (1992): Skull, in Pekingese Dog. Tomodensitometry and sex-linked difference. Revue Med. Vet. 143: 745-748.

Regedon, S.; Robina, A.; Franco, A. ; Vivo, J.M. and Lignereux, Y. (1991): Radiographic evaluation and statistical analysis of canine skull form. Dolichocephaly, Mesocephaly, Brachycephaly. Anat. Histol. Embryol. 20: 129-138.

Saber, A. S. (1989): Cranial capacity of the sheep and goat. Assiut Vet. J. 21 (42): 1-6

Saber, A.S. and Gummow, B. (2014): Skull Morphometry of the Lion (Panthera leo), Dog (Canis lupus familiaris) and Cat (Felis catus). (accepted for publication in J. Vet. Anat.)

Sandhu, P.S. and Dhingra, L.D. (1986): Cranial capacity of Indian camel. Indian Journal of Animal Sciences 56(8): 870-872.

Sarma, K. (2006): Morphological and Craniometrical Studies on the Skull of Kagani Goat (Capra hircus) of Jammu Region. Int. J. Morphol. 24(3): 449-455.

Sarma, K. and Samara, M. (2002): Anatomy of the skull of Dum pig of 
Assam. Indian J. vet. Anat., 79:708711.

Shoshani, J and Eisenberg, J.F. (1982):Elephas maximus. Mammalian Species No. 182: 1-8

Simoens, R., Poles, R. and 'lauwers, H. (1994): Morphometric analysis of foramen magnum in $\mathrm{Pe}$ kingese dogs. American Journal of Veterinary Research, 55: 33-39.

\section{Snedecor, G.W. and Cochran,} W.C. (1967): Statistical Methods, Oxford and IBH Publishing Co., Bombay.

Sonntag, C.F. (1921): The comparative anatomy of the koala (Phascolarctos cinereus) and vulpine phalanger (Trichosurus vulpecula). Proc zool soc lond: $547-577$

Sonntag, C.F. (1922): On the myology and classification of the wombat, koala, and phalangers. Proc zool soc lond: 863-896

Sudhakar, L.S.A. and Sharma, D.N. (1998): Anatomy of the skull of yak (Bos grunion). Indian J. vet. Anat., 10:5-9.

Rao,G.S. (1967): Cranial capacity of adult bovine skull. Journal of the Anatomical Society of India, 16: 121-127.
Udden, M.M.; Uddan, A.S.S.; Islam; K.N. and Islam, M.M. (2009): Clinical anatomy of the head region of the Black Bengal goat in Bangladesh. Int. J. Morphol. 274): 12691273.

Wikipedia, the free encyclopedia (retrieved 15/3/2014).

Yahaya, A.; Olopade, J.O.; Kwari, D. and Wiam, I.M. (2012): Osteometry of the skull of one-humped camels. Part I: immature animals. IJAE, Vol.117, n: 23-33.

Young, A.H. (1882): The muscular anatomy of the koala (Phascolarctos cinereus). J Anat Physiol 16: 217-242.

\section{Internet sites:}

1)

http://terriblepunyrightness.wordpre ss.com/2011/02/02/the-functionalanatomy-of-sitting-part-1/ (retrieved 22/11/2013)

Corresponding address:

Prof. A.S.Saber

E-mail: saberashraf_2@yahoo.com 
Skull morphometery of three marsupial species

Saber and Gummow

Table (1): Measurements means of koala, wombat and wallaby skulls and their standard deviations (SD).

\begin{tabular}{|c|c|c|c|c|c|c|c|}
\hline No. & Parameters & $\begin{array}{c}\text { Koala } \\
\text { Mean }\end{array}$ & $\begin{array}{c}\text { Koala } \\
\text { SD }\end{array}$ & $\begin{array}{c}\text { Wombat } \\
\text { Mean }\end{array}$ & $\begin{array}{c}\text { Wombat } \\
\text { SD }\end{array}$ & $\begin{array}{c}\text { Wallaby } \\
\text { Mean }\end{array}$ & $\begin{array}{c}\text { Wallaby } \\
\text { SD }\end{array}$ \\
\hline 1 & Skull length (cm) & 12.0 & 0.9 & 16.6 & 0.8 & 13.2 & 1.4 \\
\hline 2 & Skull width (cm) & 7.0 & 0.6 & 12.9 & 0.5 & 7.4 & 0.7 \\
\hline 3 & Cranial length (cm) & 8.7 & 1.1 & 10.4 & 0.5 & 7.7 & 0.4 \\
\hline 4 & Cranial width (cm) & 5.3 & 1.4 & 5.3 & 0.5 & 4.2 & 0.2 \\
\hline 5 & Facial length (cm) & 3.6 & 0.6 & 6.4 & 0.6 & 5.6 & 1.3 \\
\hline 6 & Facial width (cm) & 6.7 & 0.5 & 9.5 & 3.0 & 6.4 & 0.5 \\
\hline 7 & $\begin{array}{c}\text { Skull weight with mandible } \\
\text { (gm) }\end{array}$ & 70.3 & 10.4 & 361.5 & 81.3 & 90.7 & 23.1 \\
\hline 8 & $\begin{array}{c}\text { Skull weight without mandi- } \\
\text { ble (gm) }\end{array}$ & 44.3 & 8.1 & 224.5 & 50.2 & 55.7 & 13.6 \\
\hline 9 & Orbital capacity (cc) & 2.9 & 0.6 & 8.6 & 1.2 & 4.6 & 1.2 \\
\hline 10 & Orbital height (cm) & 2.0 & 0.1 & 3.4 & 0.1 & 2.3 & 0.3 \\
\hline 11 & Orbital width (cm) & 1.8 & 0.2 & 2.9 & 0.2 & 2.1 & 0.2 \\
\hline 12 & $\begin{array}{c}\text { Inter-orbital distance (ros- } \\
\text { tral) (cm) }\end{array}$ & 4.2 & 0.5 & 6.9 & 0.8 & 4.1 & 0.6 \\
\hline 13 & $\begin{array}{c}\text { Inter-orbital distance (mid- } \\
\text { dle) (cm) }\end{array}$ & 4.1 & 0.7 & 6.4 & 0.8 & 3.6 & 0.9 \\
\hline 14 & $\begin{array}{c}\text { Inter-orbital distance (cau- } \\
\text { dal) (cm) }\end{array}$ & 4.3 & 0.3 & 7.2 & 1.6 & 3.2 & 0.2 \\
\hline 15 & Cranial capacity (cc) & 20.0 & 2.4 & 61.7 & 11.8 & 33.5 & 3.7 \\
\hline 16 & Mandibular length (cm) & 9.8 & 0.9 & 12.7 & 0.9 & 9.9 & 1.0 \\
\hline
\end{tabular}

Table (2): Means of the cranial, orbital, facial and skull/cephalic indices in Koala, Wombat and Wallaby.

\begin{tabular}{|c|c|c|c|}
\hline Parameter & Koala & Wombat & Wallaby \\
\hline Cranial Index & 60.919 & 50.961 & 54.545 \\
\hline Orbital Index & 90.00 & 85.294 & 91.304 \\
\hline Facial Index & 186.111 & 148.437 & 114.286 \\
\hline Skull/cephalic Index & 58.333 & 77.710 & 56.060 \\
\hline
\end{tabular}


Skull morphometery of three marsupial species

Table (3): Means of the cranial, orbital, facial and skull/cephalic indices in lion, dog and cat (Saber and Gummow, 2014), one-humped camel (Yahaya et al, 2012), Tibetan Gazelle (Zhu, 2012)

\begin{tabular}{|c|l|l|c|c|c|}
\hline Parameter & Lion & Dog & Cat & Camel & Gazelle \\
\hline Cranial Index & 70.44 & 86.07 & 120.58 & $41.42 \pm 0.43$ & $11.37 \pm 1.24$ \\
\hline Orbital Index & 72.64 & 84.85 & 82.14 & - & - \\
\hline Facial Index & 99.27 & 37.92 & 118 & $96.35 \pm 0.95$ & $58.71 \pm 0.30$ \\
\hline Skull/cephalic Index & 2800 & 1004 & 680 & $40.99 \pm 0.33$ & $43.22 \pm 0.44$ \\
\hline
\end{tabular}

Table (4): The average cranial capacity of some animal species and man

\begin{tabular}{|c|c|c|}
\hline Authors & $\begin{array}{l}\text { Animal } \\
\text { Species }\end{array}$ & $\begin{array}{c}\text { Average cranial capaci- } \\
\text { ty }(\mathrm{cc})\end{array}$ \\
\hline Miller et al. & Dog & $82-92-104$ \\
\hline (1967) & Ox & $440+39.50$ \\
\hline$(1967)$ & Buffalo & $627.45+62.12$ \\
\hline Sandhu \& Dhingra & Camel & $587.14+14.89$ \\
\hline$(1988)$ & Sheep & $122.154+5.355$ \\
\hline$(1988)$ & Goat & $95.846+8.119$ \\
\hline Saber and Gummow (2014) & Lion & $207 \pm 24.49$ \\
\hline Chaturvedi \& Harneja (1962) & Man & $1296-1484$ \\
\hline Drennan & Man & $1296-1484$ \\
\hline Wikipedia, the free encyclopedia & Orangutans & $275-500$ \\
\hline Wikipedia, the free encyclopedia & Chimpanzees & $275-500$ \\
\hline Wikipedia, the free encyclopedia & Gorillas & $340-752$ \\
\hline Wikipedia, the free encyclopedia & Humans & $1100-1700$ \\
\hline Wikipedia, the free encyclopedia & Neanderthals & $1200-1700$ \\
\hline Osborn & Asian elephant & 6.652 \\
\hline Sarma & Kagani goat & 113 \\
\hline Yahaya et al. & One-humped camel & $487.92 \pm 7.55$ \\
\hline
\end{tabular}



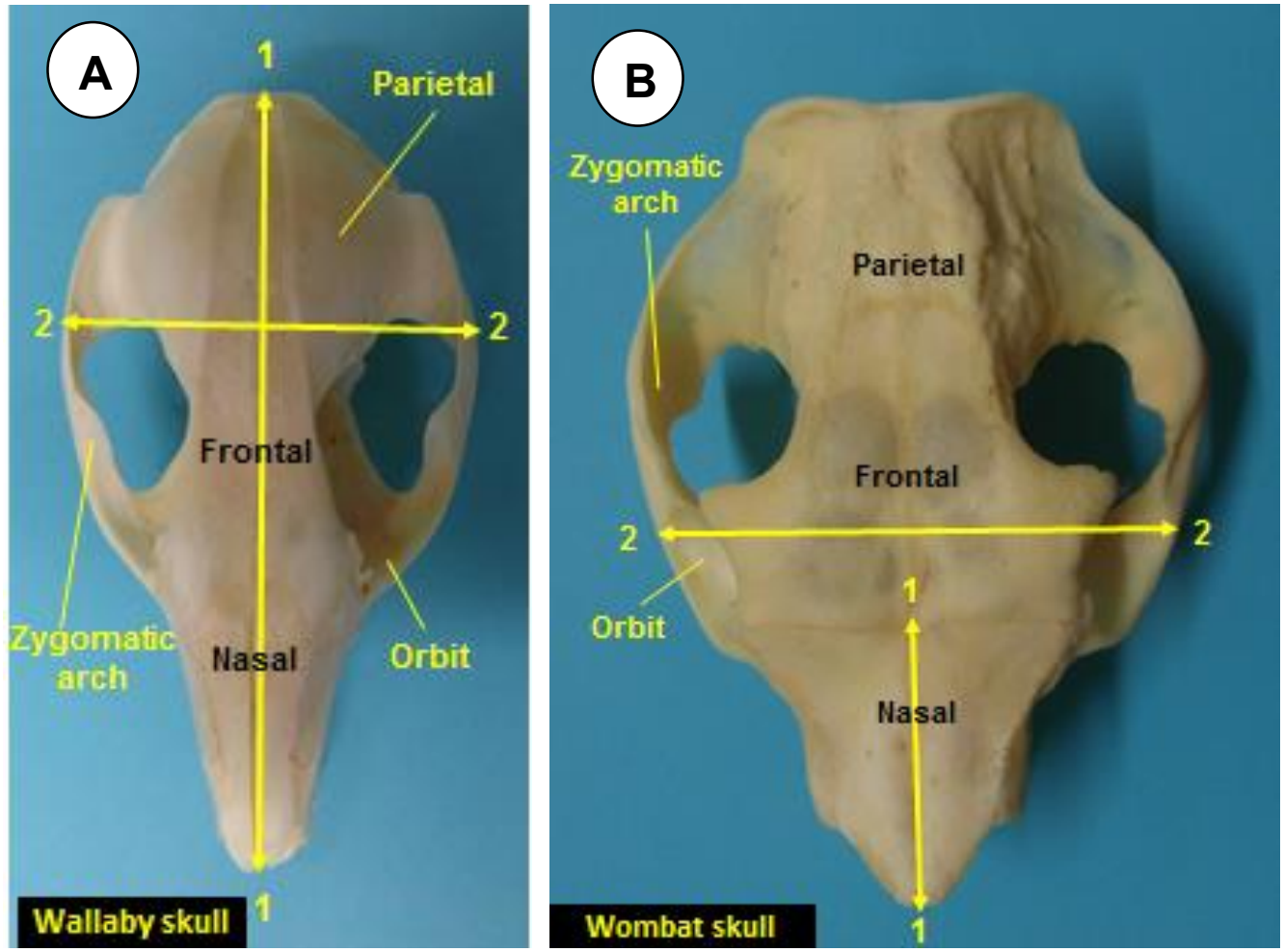

Fig (1): (A) Dorso-ventral view of the skull of the Wallaby showing the skull parameters; 1-1 skull length, 2-2 skull width. (B) Dorso-ventral view of the skull of the Wombat showing the facial parameters; 1-1 facial length, 2-2 facial width.

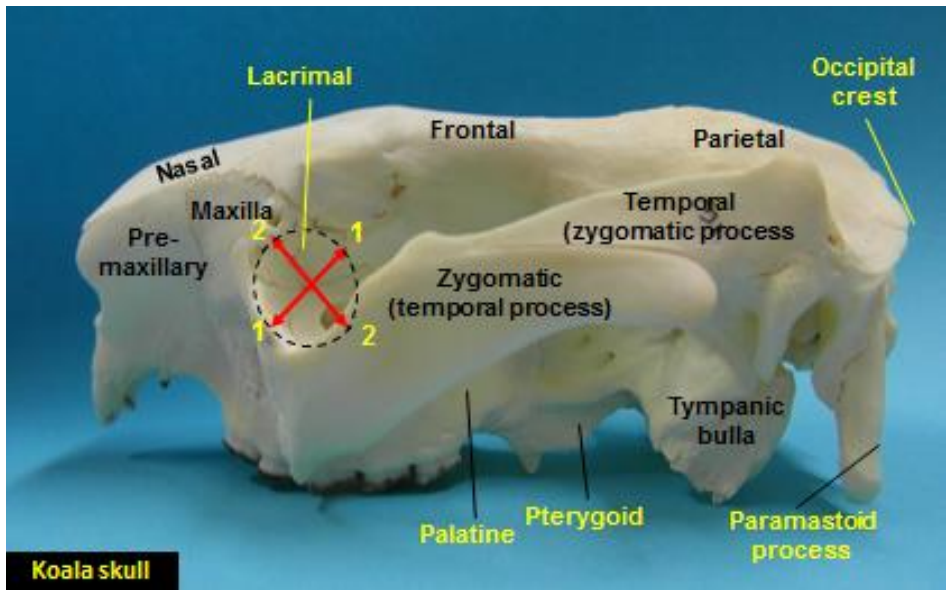

Fig (2): Lateral view of Koala skull showing the orbit dimension.

1-1 Orbital length, 2-2 Orbital width. Dotted circle indicates the orbit circumference (not completely bony 


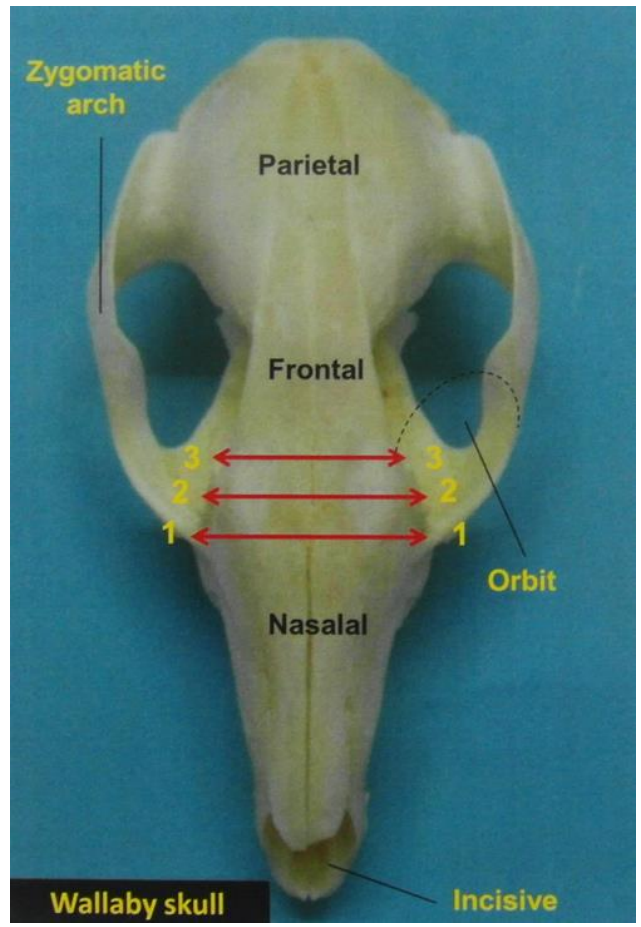

Fig (3): (A) Dorso-ventral view of the skull of the Wallaby showing the inter-orbital parameters; 1-1 Rostral, 2-2 middle, 3-3 Caudal inter-orbital distances. Dotted lines indicate orbit circumference.

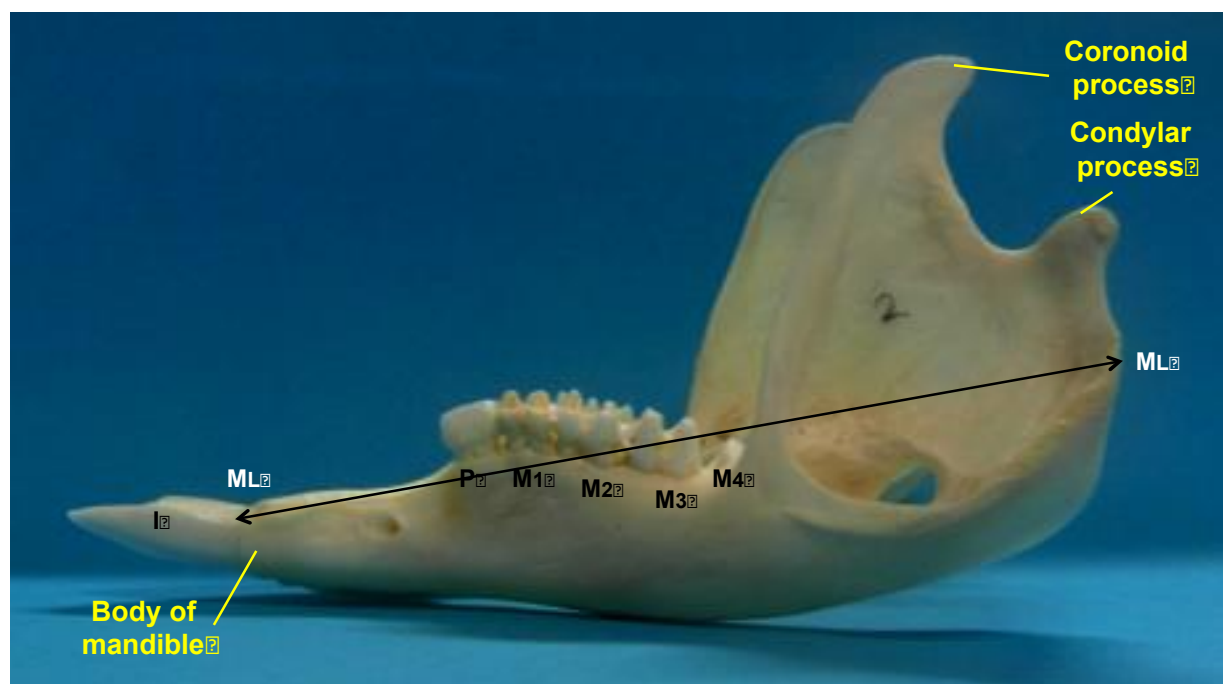

Fig (4): (A) Lateral view of the mandible of the Wallaby showing: ML-ML mandibular length (distance between incisor and caudal border of the mandible). 